\title{
Transcatheter closure of Blalock-Taussig anastomosis with brachial access in a child with obstruction of the left subclavian artery and secondary subclavian steal syndrome
}

Przezskórne zamknięcie zespolenia Blalocka-Taussig z dostępu ramiennego u dziecka z niedrożnością lewej tętnicy podobojczykowej i wtórnym zespołem podkradania

Rafał Surmacz ${ }^{1}$, Tomasz Moszura', Bartłomiej Mroziński', Artur Baszko², Michał Wojtalik², Waldemar Bobkowski', Aldona Siwińska ${ }^{1}$

1Department of Paediatric Cardiology and Nephrology, Poznan University of Medical Sciences, Poland

2Department of Cardiology, Poznan University of Medical Sciences, Poland

${ }^{3}$ Department of Paediatric Cardiac Surgery, Poznan University of Medical Sciences, Poland

Postep Kardiol Inter 2012; 8 , 3 (29): 261-264 DOI: 10.5114 /pwki.2012.30409

\begin{abstract}
In case of significant hypoxia in the course of congenital heart defect, when definite surgery is difficult, various palliative procedures are performed. One of the most frequently used is a modified Blalock-Taussig (BT) anastomosis. The BT anastomosis is closed during cardiac surgery. In some patients, BT anastomosis remains open after the surgery and requires closure by cardiac intervention using different types of closure devices. We describe a case of percutaneous closure of Blalock-Taussig anastomosis in a 4-yearold boy, with occluded left subclavian artery, presence of collateral circulation, and the subclavian artery steal syndrome to the left pulmonary artery through the patent BT anastomosis.
\end{abstract}

Key words: Blalock-Taussig anastomosis, percutaneous closure

\section{Streszczenie}

W przypadku istotnego niedotlenienia w przebiegu wrodzonej sinicznej wady serca oraz niemożności przeprowadzenia operacji radykalnej u pacjentów wykonuje się różnego rodzaju zabiegi łagodzące. Jednym z częściej wykonywanych jest zmodyfikowane zespolenie Blalocka-Taussig (BT). Elementem końcowej korekcji wady jest zamknięcie zespolenia podczas operacji kardiochirurgicznej. U niektórych pacjentów, z różnych powodów, zespolenie BT pozostaje drożne po zabiegu i wymaga zamknięcia interwencyjnego z zastosowaniem różnego rodzaju implantów. Przedstawiono przypadek przezskórnego zamknięcia zespolenia BT u 4-letniego chłopca z niedrożnością lewej tętnicy podobojczykowej z obecnością krążenia obocznego przez tętnicę kręgową oraz zespołem podkradania do lewej tętnicy płucnej przez drożne zespolenie BT.

Słowa kluczowe: zespolenie Blalocka-Taussig, zamknięcie przezskórne

\section{Introduction}

Indications, effectiveness and long-term results of palliative treatment of congenital heart defects with a modified systemic-to-pulmonary artery shunt (Blalock-Taussig [BT] shunt) are well established [1]. When the total cor- rection of a defect is made, a BT shunt is routinely closed during cardiac surgery or, less frequently, after cardiac surgery using interventional cardiology procedures. Sometimes, the situation is problematic due to the course of a shunt or the subclavian artery causing additional diagnostic and therapeutic difficulties.

Corresponding author/Adres do korespondencji:

Rafał Surmacz MD, Department of Paediatric Cardiology and Nephrology, Poznan University of Medical Sciences, 27/33 Szpitalna, 60-572 Poznan, Poland, tel.: +48 618491 370, e-mail: rsurmacz@kursyerc.pl

Praca wpłynęła: 5.07.2012, przyjęta do druku: 4.09.2012. 
The authors present a rare co-existence of an occlusion of the left subclavian artery with the presence of collateral circulation, and the vertebral artery steal syndrome to the left pulmonary artery through a patent BT shunt.

\section{Case report}

A 4-year-old boy was referred to the Department of Invasive Paediatric Cardiology with a suspected patent BT shunt. Congenital heart disease in the form of transposition of great arteries, ventricular septal defect and pulmonary stenosis (maximum pressure gradient between the right ventricle and the pulmonary trunk measured using echocardiography was $64 \mathrm{~mm} \mathrm{Hg}$ ) was diagnosed on the first day after delivery. Because of the persisting significant hypoxemia $\left(\mathrm{PO}_{2}=29.0 \mathrm{~mm} \mathrm{Hg}\right.$, oxygen saturation $=50 \%$, a modified systemic-to-pulmonary artery BT shunt was performed on the second day of life. After the surgery, the patient received aspirin at a dose 2-3 mg/kg of body weight. At 7 months of age, before the scheduled correction of the defect, diagnostic cardiac catheterization was performed. The catheterization revealed the transposition of the great arteries, ventricular septal defect, valvular pulmonary stenosis with a directly measured pressure gradient of $62 \mathrm{~mm} \mathrm{Hg}$, well-developed pulmonary arteries (both), and an occlusion of the left BT shunt (Figure 1). The Rastelli procedure using a bovine xenograft for a correction of a defect was performed at 10 months of age. Two years after the surgery, a murmur of a patent BT shunt was found on clinical examination, and subsequent echocardiographic studies revealed grad-

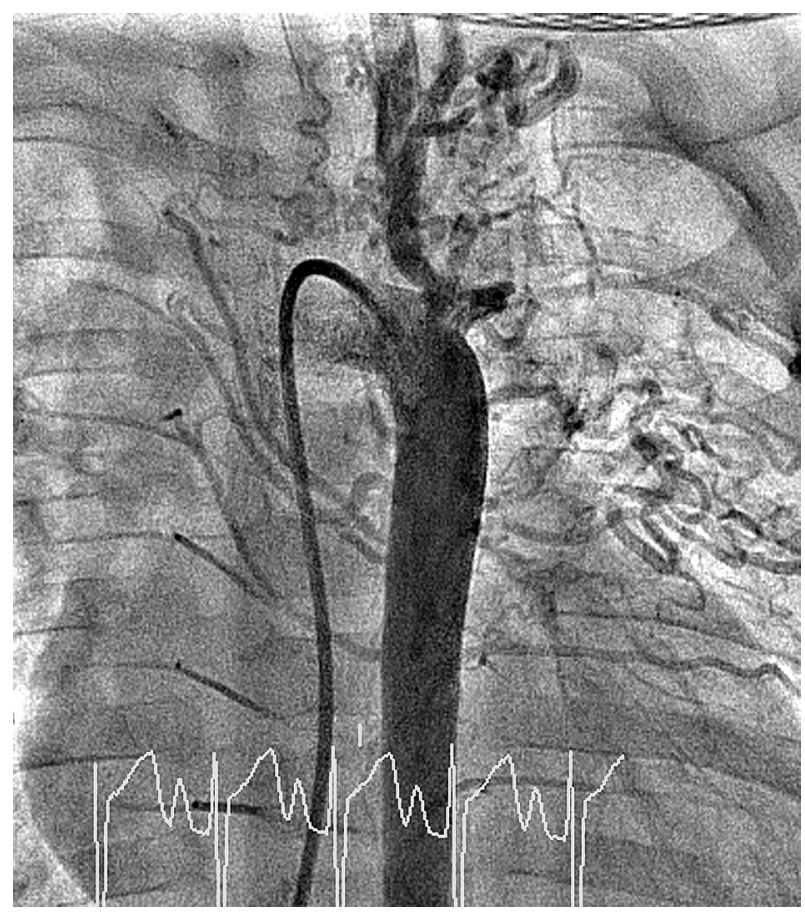

Fig. 1. Aortography prior to surgical correction Ryc. 1. Aortografia przed korektą chirurgiczna ually increasing flow in the left pulmonary artery characteristic for a left BT shunt. The boy was scheduled for cardiac catheterization with an option of shunt closure.

Cardiac catheterization was performed under general anaesthesia. After femoral artery puncture, a contrast agent was given into the descending aorta. It revealed an occlusion of the left subclavian artery (as in the preoperative study), which was supplied by collateral circulation mainly from the left vertebral artery. Additionally, after administration of a contrast medium into the ascending aorta, a weak opacification of pulmonary arteries was seen (Figure 2). Due to obstruction of the left subclavian artery, we decided to use the brachial artery for further procedures. Because of the patient's low body weight, and the risk of vascular complications, vascular puncture was abandoned and the brachial artery was surgically exposed. After the brachial artery was punctured, a $4 \mathrm{~F}$ vascular sheath (Cook Medical) was introduced through the artery under visual control. When a contrast agent was given, the inflow into the left pulmonary artery through a patent left BT shunt $4 \mathrm{~mm}$ in diameter was seen. There was a stenosis (lumen diameter of about $2 \mathrm{~mm}$ ) at the site of anastomosis with the left pulmonary artery (Figure 3). Then, an endovascular embolization coil (3 $\mathrm{mm}$ in diameter, 5 loops, MREye 3-PDA-5, Cook Medical) was introduced through the MPA $4 \mathrm{~F}$ catheter, and the shunt was sealed. After removal of a vascular sheath from the brachial artery, the artery was sutured with single stitches. No evidence of stenosis was observed, and the normal flow through the vessel was confirmed. Prophylactic doses of low molec-

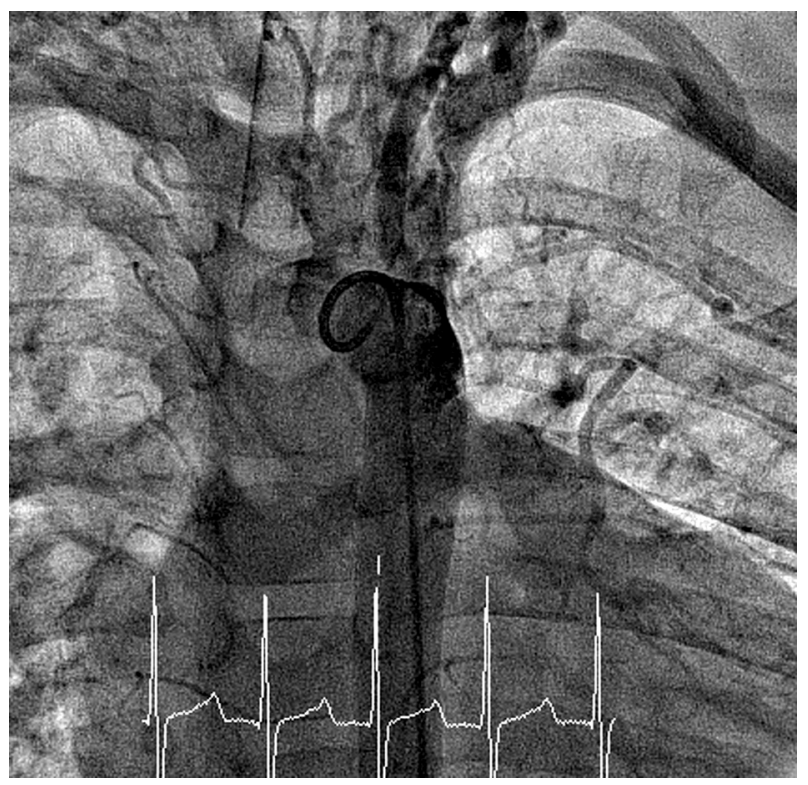

Fig. 2. Aortography 3 years after surgical correction (opacification of the pulmonary arteries is seen) Ryc. 2. Aortografia 3 lata po korekcji chirurgicznej (widoczny zarys tętnic płucnych) 


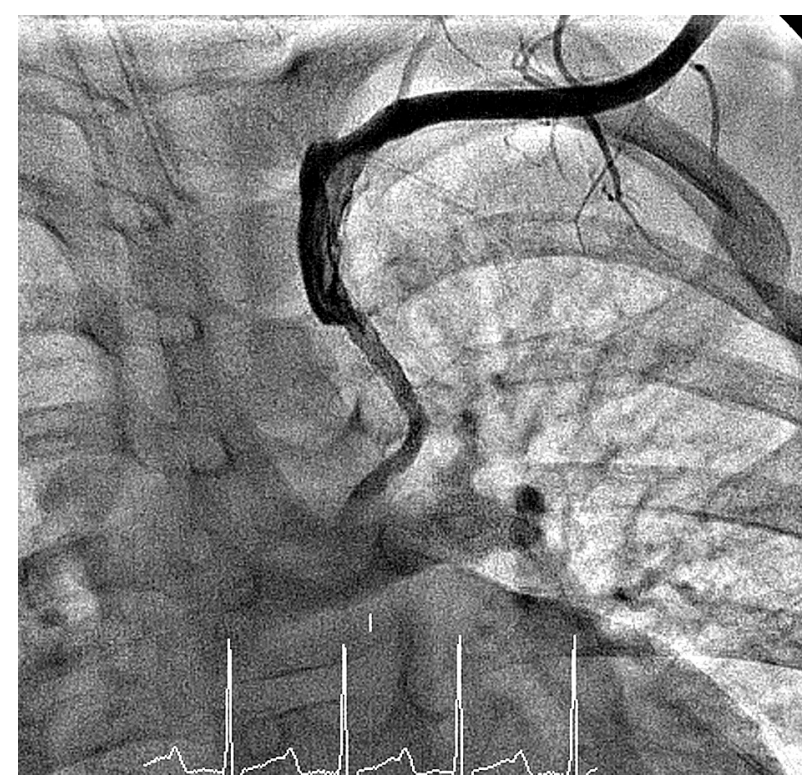

Fig. 3. A patent modified Blalock-Taussig shunt Ryc. 3. Drożne zmodyfikowane zespolenie Blalocka-Taussig

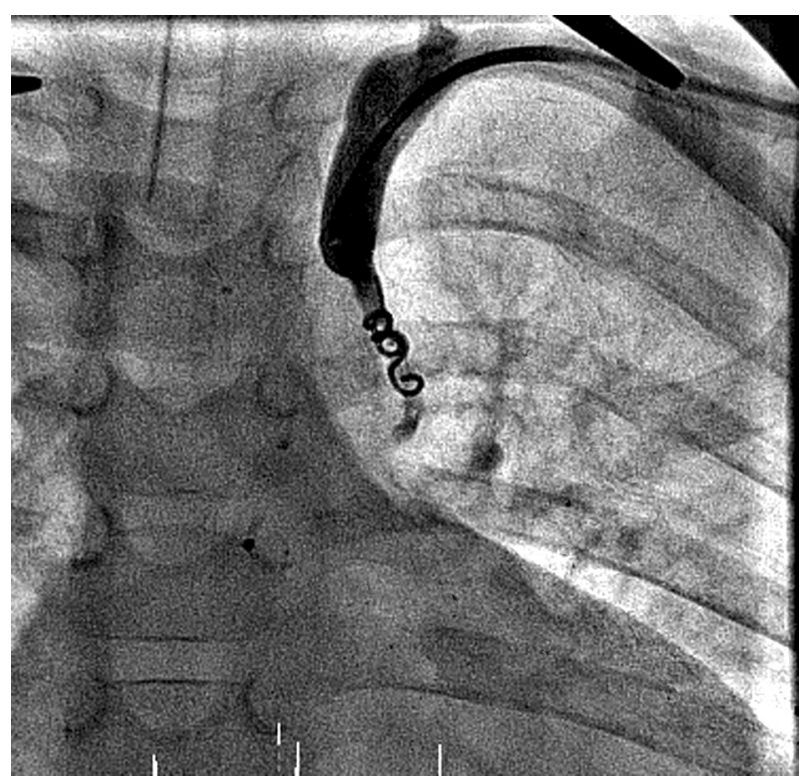

Fig. 4. Closure of a modified Blalock-Taussig shunt with a coil

Ryc. 4. Zamknięcie zmodyfikowanego zespolenia Blalocka-Taussig sprężynką wewnątrznaczyniowa typu coil

Doppler echocardiographic study revealed the flow in the pulmonary artery which may correspond to the inflow from a patent BT shunt. We did not find in the available literature a case of spontaneous closure of a shunt with subsequent spontaneous recanalization. In the current case report, spontaneous recanalization was probably associated with the development of collateral circulation through the left vertebral artery, and was facilitated by antiplatelet therapy, which was used after the correction of the boy's heart defect.

The selected type of vascular access used for the procedure also needs to be discussed. The catheterization access from the femoral vein and the retrograde cannulation of the shunt from the pulmonary artery were abandoned. This resulted primarily from unclear results of aortography (it was difficult to differentiate whether the minimum opacification of pulmonary arteries was due to the flow through a BT shunt, or collateral vessels originating from the aorta). When a decision to access the brachial artery was made, surgical exposure of the vessel and surgical suturing after the procedure were chosen intentionally. We were afraid of vascular complications and impairment of vascular perfusion of the limb, which was supplied by collateral circulation, and at the baseline (prior to the procedure) lower blood pressure and lower pulse volume were found in this limb. In our case, an intravascular embolization coil could be used safely due to the narrowing of the shunt. The choice of the coil diameter was made after detailed angiography, and assessment of the degree of BT shunt stenosis [7]. 


\section{References}

1. Di Benedetto G, Tiraboschi R, Vanini V, et al. Systemic-pulmonary artery shunt using PTFE prosthesis (Gore-Tex). Early results and long-term follow-up on 105 consecutive cases. Thorac Cardiovasc Surg 1981; 29: 143-147.

2. Culham J, Izukawa T, Burns JE, et al. Embolization of a BlalockTaussig shunt in a child. Am J Radiol 1981; 137: 413-415.

3. Morag B, Rubinstein ZJ, Smolinsky A, et al. Percutaneous closure of a Blalock-Taussig shunt. Cardiovasc Intervent Radiol 1984; 7: 218-220.

4. Tometzki AJ, Houston AB, Redington AN, et al. Closure of BlalockTaussig shunts using a new detachable coil device. Br Heart J 1995; 73: 383-384.

5. Hoyer MH, Leon RA, Fricker FJ. Transcatheter closure of modified Blalock-Taussig shunt with Gianturco-Grifka Vascular Occlusion Device. Catheter Cardiovasc Interv 1999; 48: 365-367.

6. Sivakumar K, Krishnan P, Pieris R, et al. Hybrid approach to surgical correction of tetralogy of Fallot in all patients with functioning Blalock Taussig shunts. Catheter Cardiovasc Interv 2007; 70: 256-264.

7. Burrows PE, Edwards TC, Benson LN. Transcatheter occlusion of Blalock-Taussig shunts: technical options. J Vasc Interv Radiol 1993; 4: 673-680. 